\title{
Penyesalan Keputusan Konsumen Berdasarkan Faktor Rekomendasi dan Kredibilitas Informasi
}

\author{
Faraz Umaya ${ }^{1}$ \\ Fakultas Psikologi dan Ilmu Sosial Budaya Universitas Islam Indonesia \\ Faturochman, Asip F. Hadipranata, Magda Bhinnety Etseem \\ Fakultas Psikologi Universitas Gadjah Mada
}

\begin{abstract}
The objective of this research was to empirically examine the effects of recommendation and credibility of information on consumer's regret over decision regarding purchase opportunity. Post-decisional emotion was measured in terms of five aspects of consumer's regret consisting of feeling, thought, action tendencies, actions, and emotional goal. Purchase recommendation was specified into two experimental conditions, namely recommendation and no recommendation, which signify action and inaction tendencies in consumer decision making. Credibility of information was meant as recommendation by expert and non-expert. A $2 \times 2$ factorial design was employed to test the hypotheses. The results demonstrated that consumer's regret was affected by type of recommendation and credibility of information. The highest level of regret was observed in the subjects who received no recommendation and expert condition, followed by no recommendation and nonexpert, recommendation and expert, and recommendation and non-expert. The result of analysis also revealed that credibility of information significantly influenced the types of consumer responses. This result goes with any existing consumer behaviour literatures, and warns marketers that strategy of giving price discount can backfire when consumer is disappointed.
\end{abstract}

Keywords: decision, information credibility, recommendation, regret

\begin{abstract}
Abstrak. Tujuan penelitian ini adalah untuk menguji secara empiris pengaruh rekomendasi dan kredibilitas informasi terhadap penyesalan konsumen atas keputusan mengenai peluang pembelian. Emosi pasca-putusan diukur dari lima aspek penyesalan (konsumen) yang terdiri dari perasaan, pikiran, kecenderungan bertindak, bertindak, dan tujuan emosional. Rekomendasi pembelian ditentukan dalam dua kondisi eksperimen, yaitu ada rekomendasi dan tidak ada rekomendasi, yang menandakan kecenderungan untuk bertindak atau tidak bertindak dalam pengambilan keputusan konsumen. Kredibilitas informasi diartikan sebagai rekomendasi dari informan ahli dan non-ahli. Desain $2 \times 2$ faktorial digunakan untuk menguji hipotesis. Hasil penelitian menunjukkan bahwa penyesalan konsumen dipengaruhi oleh jenis rekomendasi dan kredibilitas informasi. Tingkat tertinggi penyesalan terjadi pada kondisi subyek yang tidak menerima rekomendasi dan informan ahli, diikuti oleh tidak ada rekomendasi dan informan nonahli, ada rekomendasi dan informan ahli, dan ada rekomendasi dan informan non-ahli. Hasil analisis juga menunjukkan bahwa kredibilitas informasi secara signifikan mempengaruhi perilaku konsumen. Hasil penelitian ini sangat sesuai dengan literatur perilaku konsumen yang ada, dan mengirim pesan peringatan ke dunia pemasaran: bahwa strategi memberkan harga promosi (pengurangan) dapat menjadi bumerang ketika konsumen kecewa.
\end{abstract}

Kata kunci: penyesalan, keputusan, kredibilitas informasi, rekomendasi

\footnotetext{
${ }^{1}$ Korespondensi mengenai isi artikel ini dapat dilakukan melalui: umarmoyo@yahoo.com
} 
Sebagai makhluk ekonomi, konsumen diasumsikan akan selalu mengoptimalkan hasil transaksinya, namun dalam kehidupan sehari-hari hal itu sulit diwujudkan. Teori Simon (2001), bounded rationality, menegaskan bahwa rasionalitas manusia terbatas. Manusia mempunyai keterbatasan kognisi dalam memproses informasi untuk pengambilan keputusan. Berdasarkan teori bounded rationality ini diasumsikan banyak keputusan konsumen berpotensi tidak optimal. Menurut Zeelenberg dan Pieters (2007) setiap kali orang melakukan keputusan yang salah akan berimplikasi pada munculnya regret atau emosi penyesalan. Satu atau dua frekuensi penyesalan yang dialami konsumen mungkin dapat diatasi melalui sistem regulasi emosi, tetapi kalau ratusan bahkan ribuan sensasi penyesalan yang muncul, maka sistem regulasi emosi manusia tidak dapat berjalan secara optimal. Hasil penelitian Schwartz (2004) menyebutkan bahwa akumulasi dari pengalaman penyesalan yang dialami konsumen di Amerika telah membuat banyak masyarakat Amerika hidup dalam kondisi yang jauh dari bahagia dan tidak sedikit yang mengalami depresi.

Kajian teori penyesalan (regret theory) tidak hanya menarik, tetapi juga penting dilakukan, karena sudah banyak bukti bahwa penyesalan bukan hanya sekadar reaksi afektif dari hasil keputusan buruk, lebih dari itu, penyesalan merupakan emosi yang memberi arah pada perilaku seseorang (Zeelenberg \& Pieters, 2007). Dalam konteks Indonesia, kajian teori penyesalan menjadi lebih menarik, karena pihak produsen, toko retail besar maupun kecil di Indonesia, pada umumnya kurang memperhatikan kondisi psikologis konsumen. Misalnya, pada retail atau outlet, biasanya kita temukan tulisan seperti ini, "Barang yang sudah dibeli tidak dapat dikembalikan" atau "Memecahkan barang berarti anda membelinya". Kalimat-kalimat seperti ini tentu saja sangat berpotensi memunculkan penyesalan konsumen, bahkan sebelum melakukan pembelian, yang dikenal sebagai gejala "antisipasi penyesalan".

Berdasarkan studi literatur, pemahaman konsep-konsep yang berkaitan dengan penelitian dideskripsikan sebagai berikut: Menurut Bell (1982), Loomes dan Sugden (1987), teori penyesalan dibangun berdasarkan dua asumsi. Pertama, pada dasarnya konsumen cenderung membandingkan antara hasil (outcome) dari keputusannya memilih dengan hasil dari apa yang mereka akan terima seandainya melakukan pilihan yang berbeda. Kedua, pada dasarnya konsumen cenderung menganti sipasi emosi penyesalan sebelum membuat keputusan, karenanya seringkali mereka mengubah pilihan untuk menghindari potensi penyesalan

Dari dua kecenderungan ini, teori penyesalan dapat dikaji baik sebagai anteseden maupun konsekuensi. Studi ini fokus pada penyesalan sebagai konsekuensi, dengan alasan penyesalan dalam konteks konsekuensi pasca keputusan mempunyai peran strategis dalam pengembangan disiplin perilaku konsumen dan aplikasinya untuk meningkatkan kondisi psikologis konsumen yang lebih baik.

Kemudian mengenai konsep rekomendasi, dalam penelitian ini, diartikan sebagai bentuk informasi yang disampaikan kepada atau diperoleh konsumen untuk kebutuhan pengambilan keputusan. Dalam literatur, rekomendasi dikategorikan sebagai salah satu kajian tentang 
pengaruh faktor personal atau word-ofmouth research (Senecal \& Nantel, 2004). Andreasen (1968, dalam Senecal \& Nantel, 2004) mengkategorikan jenis-jenis rekomendasi ke dalam: (1) rekomendasi yang bersifat menganjurkan dan tidak ditujukan pada orang tertentu (Impersonal advocat). Contoh: rekomendasi yang diberikan oleh sebuah media massa.; (2) rekomendasi yang diberikan sebuah lembaga independen dan tidak ditujukan kepada orang tertentu (Impersonal independent). Contoh: rekomendasi yang diberikan oleh sebuah lembaga konsumen; (3) rekomendasi yang bersifat menganjurkan dan ditujukan kepada orang tertentu (Personal advocate). Contoh: rekomendasi yang diberikan oleh seorang pelayan toko; dan (4) rekomendasi yang diberikan oleh perorangan yang independen dan ditujukan kepada orang tertentu (Personal independent). Contoh: rekomendasi diberikan oleh teman dan ditujukan kepada teman atau keluarga. Konsep rekomendasi yang diterapkan dalam studi ini adalah rekomendasi tipe ketiga, yakni jenis rekomendasi yang diberikan oleh pelayan toko, yang bersifat menganjurkan.

Rekomendasi dari seorang pelayan toko diasumsikan bisa berupa: (1) memberi rekomendasi untuk membeli; (2) memberi rekomendasi untuk tidak membeli; (3) tidak memberi rekomendasi untuk membeli; dan (4) tidak memberi rekomendasi untuk tidak membeli. Dalam studi ini, tipe rekomendasi dikategorikan antara: memberi rekomendasi untuk membeli dan tidak memberi rekomendasi untuk membeli. Kategori ini dipilih untuk mengetahui perbedaan tingkat responsibilitas konsumen antara yang mendapat rekomendasi dan tidak mendapat rekomendasi. Perbedaan ini sekaligus untuk mengetahui perbedaan tingkat penyesalan antara yang mendapat rekomendasi dengan yang tidak mendapat rekomendasi.

Dalam teori penyesalan, konsumen yang mendapatkan rekomendasi dengan yang tidak mendapatkan rekomendasi akan mempunyai pengaruh yang berbeda dalam memunculkan tingkat penyesalan pasca pengambilan keputusan. Konsumen yang mendapat rekomendasi diasumsikan mempunyai responsibilitas yang lebih rendah dibandingkan konsumen yang tidak mendapatkan rekomendasi ketika mengambil keputusan. Oleh karena, tingkat responsibilitas berpengaruh positif terhadap penyesalan, maka konsumen yang mendapatkan rekomendasi diasumsikan akan mempunyai tingkat penyesalan yang lebih rendah dibandingkan konsumen yang tidak mendapat rekomendasi.

Selain rekomendasi, penelitian ini juga akan menguji faktor kredibilitas informasi atau sumber informasi yang dapat dipercaya atau tidak dapat dipercaya. Dalam studi ini, kredibilitas informasi diklasifikasikan sebagai sumber informasi dari seorang ahli dan non-ahli. Kredibilitas informasi didefinisikan sebagai tingkat pengetahuan atau kecakapan teknis yang dimiliki individu mengenai produk atau merek tertentu, yang didasari pada tingkat pemahaman mengenai produk atau merek.

Studi mengenai pentingnya faktor informasi terhadap munculnya penyesalan dilakukan Tsiros dan Mittal (2000). Menurut mereka informasi terhadap produk yang tidak dibeli (forgone) sangat dibutuhkan untuk munculnya penyesalan. Apabila kualitas dari produk yang tidak dibeli ternyata lebih baik, maka penyesalan akan muncul, sebaliknya bila produk yang tidak dibeli berkualitas lebih buruk maka perasaan kegembiraan (rejoicing) yang muncul. Penelitian faktor informasi lainnya dilakukan Zeelenberg et al. (2002). 
Mereka mengatakan bahwa informasi sebelumnya tentang kualitas dari hasil keputusan sangat menentukan apakah "bertindak" akan lebih berpengaruh atau tidak terhadap penyesalan, dibandingkan dengan "tidak bertindak". Apabila informasi sebelumnya mengatakan positif maka "tidak bertindak" (status quo) akan lebih baik dan tidak memunculkan penyesalan. Sebaliknya bila informasi sebelumnya negatif maka "tidak bertindak" akan berpotensi memunculkan penyesalan. Kajian faktor kredibilitas informasi terhadap penyesalan tidak ditemukan dalam literatur, penelitian ini merupakan upaya pengembangan dari kajian yang ada.

Dalam studi ini pengujian tentang pengaruh tipe rekomendasi dan kredibilitas informasi terhadap penyesalan dilakukan melalui keputusan "bertindak" atau "tidak bertindak", sehingga sebelum menganalisis hubungan pengaruh rekomendasi dan kredibilitas informasi terhadap penyesalan, terlebih dahulu dilakukan pengujian tentang pengaruh rekomendasi dan kredibilitas informasi terhadap keputusan.

Variabel keputusan, dalam penelitian ini, dipahami berdasarkan teori yang dikembangkan Kahneman dan Tversky (1982, dalam Zeelenberg, et al. 2000), bahwa seseorang yang memutuskan untuk bertindak akan mengalami tingkat penyesalan yang lebih besar dibandingkan orang yang memutuskan "tidak bertindak", ketika hasil keputusannya samasama buruk. Kahneman dan Miller (1986) dengan menggunakan teori norma (the norm theory) menjelaskan mengapa bertindak lebih menyesal dibandingkan tidak bertindak. Menurut teori ini, setiap objek maupun peristiwa akan menghasilkan normanya sendiri. Normalitas dari stimulus dievaluasi dengan membandingkan terhadap norma-norma yang muncul.
Tindakan abnormal (menyimpang dari norma) akan lebih memudahkan orang untuk berpikir counterfactual (kebalikan dari faktualnya) dari apa yang akan terjadi. Hasilnya bahwa tindakan abnormal diasumsikan akan menyebabkan orang akan lebih bertanggungjawab (responsibilitas) dan lebih memungkinkan mengalami penyesalan terhadap apa yang terjadi dibandingkan tindakan yang normal.

Menurut Gilovich dan Medvec (1995), berbeda dengan Kahneman dan Tversky, tingkat penyesalan antara bertindak versus tidak bertindak tergantung dari pola waktu. Ketika waktunya singkat (jangka pendek) maka "bertindak" akan memunculkan penyesalan yang lebih besar, tetapi sebaliknya dalam jangka panjang justru "tidak bertindak" akan memunculkan penyesalan yang lebih besar.

Mengomentari penelitian Gilovich, Medvec, dan Kahneman (1995) menegaskan bahwa jangka pendek (short-term) dan jangka panjang (long-term) mengenai penyesalan merupakan dua tipe penyesalan yang berbeda. Penyesalan jangka pendek (short-term regret) dapat dikatakan sebagai hot regret, yakni reaksi emosional secara langsung terhadap hasil keputusan. Penyesalan jangka panjang (long term regret) dapat dikatakan sebagai wistful regret, yakni emosi yang berhubungan dengan fantasi sedih maupun senang terhadap apa yang seharusnya terjadi. Dengan demikian, kritik dari Gilovich dan Medvec tidak mementahkan prinsip bahwa bertindak akan berdampak pada tingkat penyesalan yang lebih besar dibandingkan tidak bertindak.

Menurut Zeelenberg, van Dijk, van den Bos, dan Pieters (2002), pada umumnya orang mengambil keputusan dalam pola yang sangat sederhana yakni: win stay-lose change (kalau menang tetap, kalau kalah berpindah). Menurut Zeelenberg et 
al. (2002) bahwa keputusan seseorang itu merupakan respons dari hasil sebelumnya. Apabila hasil sebelumnya negatif, maka bertindak justru akan lebih baik (lebih normal) dan tentu akan lebih rendah penyesalan-nya. Contoh sederhana, dalam bidang politik, ketika seorang pemimpin politik buruk kinerjanya, maka memilih kandidat lain (bertindak) lebih baik (normal) dari pada tetap memilih dia (status quo atau tidak bertindak).

Studi ini menerapkan beberapa teori di atas dalam konteks dimana konsumen menghadapi kondisi ketidakpastian untuk mengambil keputusan. Dalam kehidupan sehari-hari, konsumen seringkali mengalami kondisi kurang ideal, misalnya, produk yang dicari ternyata tidak ada di toko. Hasil penelitian Fitzsmons (2000) menyebutkan bahwa kasus stok barang habis akan memengaruhi kepuasan konsumen dan pada akhirnya secara tidak langsung berpengaruh pada eksistensi toko besar atau retail.

Keputusan konsumen untuk membeli atau tidak membeli dalam kondisi dimana produk yang dicari tidak ada, didasari proses pencarian informasi individu mengenai produk alternatif yang tersedia. Menurut Fitzsmons (2000) proses pencarian informasi yang dilakukan individu sebelum mengambil keputusan adalah memperbandingkan antara produk yang dicari dengan produk yang tersedia, dari proses ini setidaknya melahirkan tiga kondisi. Pertama mungkin produk alternatif yang tersedia berkualitas lebih rendah (inferior) dibandingkan produk yang dicari. Kedua, produk yang tersedia berkualitas sama (similiar) dibandingkan produk yang dicari. Ketiga, produk alternatif yang tersedia berkualitas lebih tinggi (superior) dibandingkan produk yang dicari.

Dalam penelitian ini diskenariokan bahwa konsumen pergi ke toko untuk membeli telepon genggam, sayangnya telepon genggam yang diinginkannya sudah tidak diproduksi. Pelayan toko menawarkan alternatif produk baru sejenis dan sekelasnya tetapi baru tersedia keesokan harinya. Kemudian konsumen disodorkan sebuah pilihan. Apakah ia akan "memesan" atau "tidak memesan" produk alternatif itu? Pilihan untuk "memesan" atau "tidak memesan", diartikan juga sebagai pilihan untuk melakukan tindakan atau tidak melakukan tindakan. Konsumen yang memutuskan "bertindak", dan ternyata produk yang dipesan tidak lebih baik dari produk yang dicari, maka diasumsikan partisipan akan mengalami penyesalan. Sebaliknya konsumen yang memutuskan, "tidak bertindak", dan ternyata produk yang tidak dipesan itu berkualitas lebih baik dari produk yang dicari, maka diasumsikan konsumen akan mengalami penyesalan. Dalam penelitian ini, penyesalan diukur dengan memberi manipulasi tipe rekomendasi (merekomendasi dan tidak merekomendasi) dan kredibilitas informasi (informan ahli dan informan non-ahli). Hasil manipulasi ini tidak langsung ditujukan kepada variabel penyesalan, melainkan kepada respons atau keputusan konsumen "bertindak" atau "tidak bertindak". Berdasarkan respons konsumen inilah kemudian diukur tingkat penyesalan konsumen.

Hubungan variabel keputusan dan penyesalan dapat dijelaskan sebagai berikut. Konsumen yang memutuskan "bertindak", dan hasil keputusannya buruk, akan mengalami tingkat penyesalan yang lebih besar dibandingkan konsumen yang memutuskan "tidak bertindak", ketika keputusannya juga buruk (Kahneman \& Tversky, 1982; dalam Zeelenberg et al., 2000).

Dalam studi ini pengujian variabel independen terhadap penyesalan tidak 
dilakukan secara bersamaan, melainkan bertahap. Pertama, faktor rekomendasi dan kredibilitas informasi diuji pengaruhnya terhadap variabel keputusan. Dari hasil pengujian ini, kemudian dilanjutkan pengujian faktor rekomendasi dan kredibilitas informasi terhadap penyesalan. Terakhir, faktor keputusan diuji pengaruhnya terhadap penyesalan. Ketiga pengujian ini merupakan analisis utama dari penelitian. Analisis temuan tambahan dilakukan pada rekomendasi, kredibilitas informasi dan keputusan terhadap penyesalan, dan pengujian rekomendasi dan kredibilitas informasi terhadap penyesalan berdasarkan keputusan.

Pola pengujian seperti ini dilakukan berdasarkan data penelitian bahwa variabel keputusan tidak dimanipulasi untuk mengetahui pengaruhnya terhadap penyesalan. Secara statistik, variabel keputusan memang dapat diuji secara bersama dengan rekomendasi dan kredibilitas informasi terhadap penyesalan, tetapi secara logika eksperimen, keputusan tidak termasuk variabel yang dikontrol pengaruhnya. Oleh karena itu, desain penelitian ini adalah analisis varians (anava) dua jalur $(2 \times 2)$.

Tujuan penelitian ini, pertama untuk mengetahui dan menguji secara empiris pengaruh faktor rekomendasi dan kredibilitas informasi terhadap keputusan. Kedua, mengetahui dan menguji secara empiris pengaruh faktor rekomendasi dan kredibilitas informasi terhadap penyesalan. Kemudian, juga bertujuan menguji pengaruh keputusan terhadap penyesalan. Terakhir, menguji interaksi faktor rekomendasi, kredibilitas informasi dan keputusan terhadap penyesalan.

Hipotesis penelitian ini, yakni: (H1). Konsumen yang mendapatkan rekomendasi, cenderung memutuskan "bertindak" dibandingkan konsumen yang tidak men- dapat rekomendasi. (H2). Konsumen yang mendapatkan informasi dari informan ahli, cenderung memutuskan "bertindak" dibandingkan konsumen yang mendapatkan informasi dari informan non-ahli. (H3) Konsumen yang mendapatkan rekomendasi, mempunyai tingkat penyesalan yang lebih rendah dibandingkan yang tidak mendapatkan rekomendasi. (H4). Konsumen yang mendapatkan informasi dari informan ahli, mempunyai tingkat penyesalan yang lebih rendah dibandingkan konsumen yang mendapatkan informasi dari informan non-ahli. (H5). Konsumen yang memutuskan bertindak, mempunyai tingkat penyesalan yang lebih besar dibandingkan yang memutuskan tidak bertindak.

\section{Metode}

Penelitian ini menggunakan desain eksperimen pengukuran pasca perlakuan dengan menggunakan penugasan secara random. Penelitian dilakukan dengan memanipulasi pada empat kondisi perlakuan. Studi eksperimen ini memakai desain faktorial dua jalur ( $2 \times 2)$. Randomisasi dalam penelitian ini dilakukan melalui proses dimana partisipan yang datang ke lokasi penelitian dipersilahkan mengambil satu dari empat kartu jenis kondisi perlakuan. Manipulasi dilakukan pada faktor rekomendasi dan kredibilitas informasi (Myers \& Hansen, 2002).

Variabel independen dalam penelitian ini adalah rekomendasi dan kredibilitas informasi. Variabel dependen dalam penelitian ini adalah Penyesalan. Variabel penyesalan diukur dari lima aspek penyesalan (respons feeling; respons thoughts; respons action tendenceis; respons action; dan respons emotivational) yang dikembangkan Zeelenberg et al. (1998) menjadi 10 aitem. Dalam studi ini kelima aspek itu 
dikembangkan menjadi 16 aitem. Data penyesalan dalam studi ini adalah semua jawaban yang dituangkan dalam bentuk skoring antara 1 (sangat tidak sesuai) sampai 7 (sangat sesuai).

Partisipan penelitian ini adalah mahasiswa S1 fakultas X angkatan 2007 sampai dengan 2010, baik laki-laki maupun perempuan. Jumlah partisipan yang terlibat sebanyak 320 orang dari total 770 mahasiswa untuk keempat angkatan tersebut.

Untuk melengkapi metode eksperimen, studi ini juga menerapkan metode kualitatif. Pendekatan kualitatif ini dilakukan dengan argumentasi bahwa dari data penelitian yang diperoleh menunjukan bahwa ada tiga aitem yang tidak dapat dijawab secara memadai melalui isian kuesioner, tetapi setelah dilakukan wawancara dan menanyakan untuk ketiga aitem tersebut hasilnya sangat memadai.

\section{$\mathrm{H}$ a $\mathrm{s}$ i 1}

Hasil penelitian menunjukan bahwa jumlah partisipan pada masing-masing kelompok yang layak dianalisis adalah sebagai berikut. Kelompok 1 (X-A1B1) berjumlah 77 partisipan, terdiri dari perempuan sebanyak 55 dan laki-laki sebanyak 22 orang. Kelompok 2 (X-A1B2) berjumlah 80 partisipan, terdiri dari perempuan sebanyak 56 dan laki-laki sebanyak 24 orang. Kelompok 3 (X-A2B1) berjumlah 79 partisipan, terdiri dari perempuan sebanyak 49 dan laki-laki sebanyak 30 orang. Kelompok 4 (X-A2B2) berjumlah 80 partisipan, terdiri dari perempuan 63 dan laki-laki sebanyak 17 orang (keterangan: A1 = tidak rekomendasi; B1 = Informan Ahli; A2 = Rekomendasi; B2 = Informan Non-ahli).

Jumlah partisipan yang memutuskan "bertindak" jauh lebih sedikit dibandingkan yang memutuskan "tidak bertindak".
Ada 99 partisipan yang memutuskan memilih "bertindak" dan yang memutuskan "tidak bertindak" sebanyak 217 orang. Partisipan perempuan yang memutuskan "bertindak" lebih kecil dibandingkan lakilaki. Partisipan perempuan cenderung memutuskan "bertindak" ketika mendapat rekomendasi dari seorang ahli, sebaliknya akan memutuskan "tidak bertindak" ketika mendapatkan rekomendasi dari informan non-ahli.

Hasil pengujian hipotesis menunjukan sebagai berikut: Manipulasi yang diterapkan terhadap kelompok perlakuan (rekomendasi dan kredibilitas informasi) telah mempengaruhi keputusan masing-masing partisipan (selanjutnya disebut konsumen) untuk "bertindak" atau "tidak bertindak". Perbedaan keputusan ini menarik dan diuji terlebih dahulu sebelum menguji pengaruh rekomendasi dan kredibilitas informasi terhadap Penyesalan. Pengujian pengaruh rekomendasi dan kredibilitas informasi terhadap keputusan dilakukan dengan menggunakan kai-kuadrat, karena sifat kedua datanya adalah nominal dan tujuannya adalah untuk mengetahui tingkat signifikansi perbedaan frekuensi (Seniati, Yulianto \& Setiadi, 2008).

Hasil uji kai-kuadrat dari dua kelompok independen (Pearson $\chi^{2}=0,466 ; p=$ $0,495)$ menunjukan tidak ada perbedaan signifikan antar kedua kelompok perlakuan berdasarkan rekomendasi, sehingga Hipotesis 1 ditolak. Artinya, ada atau tidak adanya rekomendasi tidak berpengaruh secara signifikan terhadap keputusan "bertindak" atau "tidak bertindak". Pada perlakuan "tidak mendapat rekomendasi" yang memutuskan "bertindak" sebanyak $16,5 \%$ dan yang memutuskan "tidak bertindak" sebesar 33,2\%. Pada perlakuan "mendapat rekomendasi" yang memutuskan "bertindak" sebesar 14,9\% dan yang 
memutuskan "tidak bertindak" sebesar $35,4 \%$.

Untuk kredibilitas informasi, hasil uji kai-kuadrat dari dua kelompok independen (Pearson $\quad \chi^{2}=28.810 ; \quad p=<0,000$ ), menunjukan adanya perbedaan yang signifikan antar kedua kelompok perlakuan berdasarkan kredibilitas informasi, sehingga Hipotesis 2 diterima. Artinya rekomendasi yang berasal dari informan non-ahli telah mendorong partisipan untuk memutuskan "tidak bertindak" dibandingkan "bertindak". Pada perlakuan "informan ahli" yang memutuskan "bertindak" sebesar $22,4 \%$ dan yang memutuskan "tidak bertindak" sebesar 26,9\%. Pada perlakuan "informan non-ahli" yang memutuskan "bertindak" sebesar 8,9\% dan yang memutuskan "tidak bertindak" sebesar 41,8\%.

Berdasarkan hasil pengujian dengan kai-kuadrat mengenai faktor rekomendasi dan kredibilitas informasi terhadap faktor keputusan dapat disimpulkan, pertama sumber informasi ahli atau tidak ahli menjadi pertimbangan utama konsumen dalam mengambil keputusan, bukan ada atau tidak adanya rekomendasi. Kedua, konsumen menghindari rekomendasi yang bersumber dari orang yang tidak ahli. Artinya konsumen mengantisipasi perasaan tidak menyenangkan (penyesalan) saat mengambil keputusan.
Hasil pengujian dengan menggunakan anava dua jalur menunjukkan bahwa terdapat perbedaan penyesalan berdasar faktor rekomendasi (main effect) $(F=7,534$; $\left.d b=14 ; p<0,05 ; \eta^{2}=0,024\right)$ atau (rerata tidak rekomendasi $=34,949$ dan rekomendasi= 31,214; $\quad p=0,006$ ). Artinya faktor rekomendasi berpengaruh terhadap penyesalan. Konsumen yang tidak mendapatkan rekomendasi mempunyai tingkat penyesalan yang lebih besar dibandingkan konsumen yang mendapatkan rekomendasi. Dengan demikian Hipotesis 3 diterima. Hasil ini mengindikasikan bahwa rekomendasi sangat penting untuk memprediksi tingkat penyesalan yang dialami konsumen pasca pengambilan keputusan.

Hasil pengujian dengan menggunakan anava dua jalur menunjukan bahwa terdapat perbedaan penyesalan berdasar kredibilitas informasi (main effect) ( $F=$ 6,696; $\left.d b=314 ; p<0,05 ; \eta^{2}=0,021\right)$ atau (rerata informan ahli $=34,853$ dan rerata informan non-ahli=31,331; $\quad p=0,010)$. Namun demikian perbedaan rerata ini tidak sesuai dengan hipotesis yang ada. Secara teoritik, seharusnya konsumen yang mendapatkan rekomendasi dari informan non-ahli mempunyai tingkat penyesalan yang lebih besar dibandingkan konsumen yang mendapatkan rekomendasi dari informan ahli. Dengan demikian Hipotesis 4 ditolak. 
Tabel 1

Analisis varian tingkat penyesalan: Rekomendasi dan Kredibilitas informasi

\begin{tabular}{llcccc}
\hline \multicolumn{1}{c}{ Sumber } & V.Dependen & $\mathbf{d b}$ & $\begin{array}{c}\text { Eta } \\
\text { kuadrat }\end{array}$ & $\mathbf{F}$ & $\mathbf{p}$ \\
\hline Model terkoreksi & Penyesalan & 3 & 0,044 & 4,738 & 0,003 \\
Intercept & Penyesalan & 1 & 0,882 & 2331,523 & 0,000 \\
Rekomendasi (R) & Penyesalan & 1 & 0,024 & 7,534 & $\mathbf{0 , 0 0 6}$ \\
Kredibilitas Info (K) & Penyesalan & 1 & 0,021 & 6,696 & $\mathbf{0 , 0 1 0}$ \\
R x K & Penyesalan & 1 & 0,000 & 0,108 & $\mathbf{0 , 7 4 2}$ \\
\hline
\end{tabular}

a. $\quad R$ Squared $=0,044$ (adjusted $R$ Squared $=0,034$ )

Pengaruh faktor rekomendasi dan kredibilitas informasi terhadap penyesalan dapat dilihat pada Tabel 1. Pada tabel 1 dapat diketahui besarnya kontribusi dari masing-masing variabel bebas, serta interaksi antar variabel bebas. Kontribusi (pengaruh) faktor rekomendasi terhadap penyesalan lebih besar dibandingkan kedibilitas informasi. Hal ini berarti, faktor rekomendasi dapat lebih diandalkan untuk memprediksi tingkat penyesalan. Hal ini berarti juga bahwa faktor responsibilitas terbukti berpengaruh terhadap penyesalan, karena orang yang mendapat rekomendasi pada hakekatnya telah membagi tanggung jawab (responsibilitas) hasil keputusannya kepada orang yang memberi rekomendasi. Dengan kata lain, dia tidak memutuskan sendiri, sehingga ketika keputusannya buruk maka rasa penyesalannya relatif lebih rendah dibandingkan ketika ia memutuskan sendiri (tanpa rekomendasi). Interaksi antara faktor rekomendasi dan kredibilitas informasi terbukti tidak signifikan, yang berarti pengaruhnya terhadap penyesalan tidak secara bersamaan, melainkan sendirisendiri.

Pengujian pengaruh tipe keputusan terhadap penyesalan dilakukan dengan menggunakan uji-t. Hasil analisis uji-t menunjukan bahwa terdapat perbedaan penyesalan berdasarkan tipe keputusan $(t$ $=, 86 ; d b=314 ; p<0,00)$ atau (rerata bertindak $=41,98$ dan tidak bertindak=29,00; $p=0,00$ ).
Dengan demikian Hipotesis 5 diterima. Artinya keputusan untuk bertindak mempunyai tingkat penyesalan yang lebih besar dibandingkan tidak bertindak. Temuan ini menambah daftar panjang temuan serupa di luar negeri, tetapi di dalam negeri temuan seperti ini relatif langka. Untuk konteks Indonesia, temuan ini merupakan satu pengetahuan baru bahwa konsumen yang "bertindak" atau melakukan transaksi ekonomi dalam kondisi tidak pasti akan mempunyai beban psikologis yang lebih besar dibandingkan konsumen yang "tidak bertindak".

Pengujian pengaruh faktor keputusan, faktor rekomendasi dan kredibilitas informasi terhadap penyesalan dilakukan dengan menggunakan anava tiga jalur (2x2x2). Meskipun sebagai analisis temuan tambahan, tetapi pengujian ini penting dilakukan untuk mengetahui pengaruh ketiga faktor (faktor keputusan, rekomendasi dan kredibilitas informasi) sekaligus terhadap penyesalan. Analisis sebelumnya dengan menggunakan anava dua jalur (2x2) menunjukkan bahwa faktor rekomendasi berpengaruh terhadap penyesalan secara signifikan. Kredibilitas informasi, juga berpengaruh secara signifikan terhadap penyesalan, tetapi tidak sejalan dengan teori yang ada. Kemudian secara terpisah dengan menggunakan analisis uji$t$, hubungan faktor keputusan terhadap penyesalan juga menunjukkan pengaruh yang signifikan. Dengan demikian ketiga 
variabel (keputusan, rekomendasi dan kredibilitas informasi) masing-masing mempunyai pengaruh yang signifikan terhadap penyesalan. Pertanyaannya, apakah pengujian dari ketiga faktor tersebut secara bersama, akan menghasilkan hubungan pengaruh yang sama terhadap penyesalan?

Hasil analisis dengan menggunakan anava tiga jalur dapat dideskripsikan sebagai berikut; Pertama, terdapat perbedaan regret berdasarkan keputusan $(F=88,599 ; d b$ $=314 ; \quad p<0,05 ; \quad \eta^{2}=0,222$ ) atau (rerata bertindak $=41,98$ dan rerata tidak bertindak $=29,01 ; p=0,00$ ). Hasil ini membuktikan bahwa pengaruh faktor keputusan terhadap penyesalan tetap signifikan ketika dianalisis bersama dengan kedua prediktor lainnya. Hasil ini juga menunjukan bahwa pengaruh faktor keputusan terhadap penyesalan sangat kuat.

Kedua, terbukti terdapat perbedaan penyesalan berdasarkan faktor rekomendasi $\left(F=3,990 ; d b=314 ; p<0,05 ; \eta^{2}=0,013\right)$ atau (rerata tidak rekomendasi $=34,95$ dan rerata rekomendasi=31,21; $p=0,047)$. Hasil ini membuktikan bahwa pengaruh rekomendasi terhadap penyesalan tetap signifikan ketika dianalisis bersama dengan faktor keputusan dan kredibilitas informasi. Perbedaannya, ketika diuji bersama dengan keputusan, kekuatan pengaruh faktor rekomendasi berkurang. Sebelumnya, tanpa faktor keputusan, pengaruh faktor rekomendasi terhadap penyesalan adalah $\left(\eta^{2}=0,024\right)$, setelah dianalisis bersama dengan faktor keputusan kontribusi pengaruhnya menjadi $\left(\eta^{2}=0.013\right)$. Dengan demikian kehadiran faktor keputusan menurunkan kontribusi faktor rekomendasi terhadap penyesalan.

Ketiga, terbukti tidak terdapat perbedaan penyesalan berdasarkan kredibilitas informasi $\left(F=0,00 ; \mathrm{db}=314 ; p>0,05 ; \eta^{2}=0,00\right)$ atau (rerata informan ahli $=34,86$ dan rerata informan non-ahli=31,33; $p=0,999$ ). Hasil analisis anava tiga jalur ini membuktikan bahwa kredibilitas informasi tidak mempunyai pengaruh yang signifikan terhadap penyesalan. Hasil ini tentu berbeda dengan hasil sebelumnya, ketika kredibilitas informasi diuji dengan analisis anava dua jalur bersama dengan faktor rekomendasi yang hasilnya menunjukan signifikan, meskipun tidak sesuai dengan hipotesis yang dibuat.

Keempat, efek interaksi antara faktor keputusan dan faktor rekomendasi menunjukan ( $F=1,899 ; \quad \mathrm{db}=314 ; \quad p=0,17 ; \quad \eta^{2}=$ $0,006)$ tidak signifikan, yang berarti pengaruh faktor keputusan dan faktor rekomendasi terhadap penyesalan tidak terjadi secara bersama melainkan masing-masing. Hal ini bisa terjadi, karena faktor rekomendasi terdiri dari: ahli dan non-ahli. Ketika partisipan diberi manipulasi kredibilitas informasi dari informan non-ahli, mereka umumnya memutuskan tidak bertindak, kemudian ketika diinformasikan hasil keputusannya gagal (buruk) maka perasaan penyesalan yang dialami mereka (partisipan) tentu saja tidak besar, karena mereka tidak melakukan tindakan. Singkatnya, faktor keputusan berpengaruh terhadap penyesalan, yakni bertindak akan lebih penyesal daripada tidak bertindak, tetapi bila digabungkan dengan faktor rekomendasi, yakni ahli dan nonahli, maka hasilnya bisa berubah.

\section{Diskusi}

Hasil penelitian menyebutkan bahwa partisipan yang memutuskan "bertindak" relatif lebih sedikit dibandingkan yang memutuskan "tidak bertindak". Perbedaan ini bukanlah kebetulan, teori keputusan yang dikembangkan Kahneman dan Tversky, (1982, dalam Zeelenberg et al., 2000) mengatakan bahwa dalam kondisi 
ketidakpastian maka individu cenderung memilih untuk tidak bertindak (inaction) dibandingkan bertindak (action), karena bertindak akan menyebabkan beban psikologi yang lebih besar.

Mengapa persentase perempuan yang memutuskan "bertindak" lebih sedikit dibandingkan laki-laki? Sejumlah studi dalam bidang psikologi dan sosiologi mendukung hipotesis yang menyatakan bahwa respons perempuan dan laki-laki terhadap sebuah risiko adalah berbeda (Eckel, 2004). Hasil penelitian Eckel (2004), berupa meta-analysis, mengenai artikelartikel yang mengkaji perbedaan gender dan pengambilan keputusan berisiko dalam bidang ekonomi menyatakan bahwa dalam mengambil keputusan, perempuan umumnya berupaya untuk menghindar dari risiko dibandingkan laki-laki.

Mengapa faktor rekomendasi tidak berpengaruh signifikan terhadap keputusan konsumen (hipotesis 1)? Temuan ini dapat dijelaskan berdasarkan teori efek kepastian dari Kahneman dan Tversky (1979). Menurut teori efek kepastian (certainty effect), orang cenderung lebih menyukai pilihan yang pasti dibandingkan yang tidak pasti, ketika mengambil keputusan dalam kondisi ketidakpastian. Pada hipotesis 1, konsumen belum tahu (menghadapi ketidakpastian) apakah pemberi rekomendasi itu bisa dipercaya atau tidak. Ketika rekomendasi itu sudah pasti (hipotesis 2), misalnya berasal dari sumber informasi yang dapat dipercaya (informan ahli) maka keputusan konsumen terbukti lebih terarah untuk memutuskan "bertindak", sebaliknya ketika diinformasikan bahwa sumber informasi adalah tidak dapat dipercaya (informan non-ahli) maka keputusan konsumen adalah "tidak bertindak".

Hasil pengujian kai-kuadrat menunjukan bahwa faktor rekomendasi tidak berpengaruh signifikan terhadap keputusan, sementara kredibilitas informasi mempunyai pengaruh yang signifikan. Hasil pengujian ini, sekali lagi, membuktikan kebenaran teori efek kepastian, yaitu ketika ada kepastian bahwa yang memberikan rekomendasi itu adalah informan ahli, maka konsumen cenderung mengambil keputusan bertindak, sebaliknya ketika sumber informasi itu adalah informan non-ahli, maka konsumen cenderung mengambil keputusan tidak bertindak.

Temuan bahwa faktor rekomendasi berpengaruh signifikan terhadap penyesalan (hipotesis 3) adalah menarik, karena sebelumnya ketika faktor rekomendasi diuji pengaruhnya terhadap faktor keputusan (hipotesis 1), hasilnya tidak signifikan. Ada atau tidak adanya rekomendasi tidak berpengaruh terhadap keputusan konsumen, tetapi ketika diuji pengaruhnya terhadap penyesalan, terbukti bahwa konsumen yang tidak mendapat rekomendasi mempunyai tingkat penyesalan yang lebih besar. Hal ini menunjukan bahwa rekomendasi merupakan faktor penting dalam memprediksi tingkat penyesalan pasca keputusan.

Hasil studi kualitatif berupa wawancara yang dilakukan untuk studi ini menunjukan bahwa responsibilitas berpengaruh terhadap penyesalan. Hal ini berdasarkan perbandingan antara kasus yang menimpa Astuti (nama samaran) dengan kasus yang dialami Dede (nama samaran). Astuti dan Dede sama-sama mahasiswa S1 fakultas X angkatan 2009. Astuti dan Dede sama-sama mengalami penyesalan dalam membeli telepon genggam. Bedanya, Astuti mengambil keputusan sendiri dan tidak mendengar nasehat orang tua dan temannya, sementara Dede membeli telepon genggam bersama orang tua. Penyesalan yang dialami Dede hanya dua hari setelah 
itu ia bisa melupakan, tetapi penyesalan yang dialami Astuti lebih dari satu bulan. Astuti bahkan trauma dengan telepon genggam yang dibelinya. Telepon genggam yang dibelinya tidak diperbaiki dan juga tidak dijual tetapi disimpannya dalam almari. "saya malas melihatnya, apalagi membawanya, setiap saya lihat Telepon genggam itu, saya teringat orang (pelayan toko) yang sudah menipu saya," kata Astuti. Berdasarkan hasil wawancara tersebut, jelas menunjukan adanya pengaruh responsibilitas terhadap penyesalan pasca keputusan. Semakin tinggi tingkat responsibilitas, semakin besar tingkat penyesalan yang dialaminya.

Penjelasan yang dapat diberikan untuk hipotesis 4 (ditolak) sebagai berikut: ketika partisipan diberi manipulasi kredibilitas informasi atau informasi dari informan non-ahli, mereka umumnya memutuskan "tidak bertindak". Kemudian, ketika diinformasikan hasil keputusannya gagal (buruk) maka perasaan penyesalan yang dialami mereka, tentu saja tidak besar, karena mereka tidak melakukan tindakan. Ini kemungkinan yang menyebabkan mengapa tingkat penyesalan justru lebih besar pada informan ahli bukan informan non-ahli. Dengan kata lain, karena pengujian kredibilitas informasi terhadap penyesalan dilakukan melalui faktor keputusan, sehingga tidak otomatis kredibilitas informasi dapat diprediksi pengaruhnya terhadap penyesalan, tetapi harus dilihat dahulu keputusan apa yang dibuat partisipan (konsumen) atas perlakuan pada kredibilitas informasi. Hal ini juga mengindikasikan bahwa pengaruh faktor keputusan terhadap penyesalan jauh lebih besar dibandingkan pengaruh kredibilitas informasi terhadap penyesalan. Dengan demikian, sebenarnya, antara faktor keputusan dan faktor penyesalan yang dialami konsumen berdasarkan kredibilitas informasi adalah logis dan sesuai dengan teori penyesalan.

Kredibilitas informasi dengan variasi: informan ahli dan informan non-ahli dimaksudkan sebagai kategori dari konsep responsibilitas. Bila kredibilitas informasi tidak berpengaruh signifikan terhadap penyesalan berarti penelitian ini juga membuktikan bahwa responsibilitas tidak mempunyai pengaruh terhadap penyesalan. Hal ini juga yang dialami Connolly, Ordonez, dan Coughlan (1997). Hasil penelitian mereka menyebutkan bahwa tidak terbukti pengaruh responsibilitas terhadap penyesalan, tetapi menurut Zeelenberg et al. (1998) bahwa responsibilitas tidak terbukti pengaruhnya terhadap penyeaslan, disebabkan karena apa yang dilakukan Connolly, et al. (1997) adalah tidak mengukur penyesalan secara langsung. Seandainya diukur secara langsung maka responsibilitas sebagai prediktor penyesalan akan ditemukan.

Berdasarkan hasil analisis varian tiga jalur (sebagai analisis temuan tambahan) dapat ditarik beberapa kesimpulan. Pertama, peran faktor keputusan sangat dominan dibandingkan kedua faktor lainnya. Bahkan dapat dikatakan bahwa faktor keputusan dapat berperan sebagai variabel moderator antara kedua prediktor lainnya terhadap penyesalan, karena pengaruh faktor rekomendasi dan kredibilitas informasi dapat diturunkan atau bahkan dihilangkan kekuatan pengaruhnya terhadap penyesalan. Kedua, pengaruh faktor rekomendasi dan kredibilitas informasi terhadap penyesalan sangat dipengaruhi faktor keputusan, dengan demikian pengujian pengaruh faktor rekomendasi dan kredibilitas informasi terhadap penyesalan melalui faktor keputusan pada studi ini terbukti sangat menarik. 
Temuan menarik dalam penelitian ini, ketika konsep responsibilitas diwujudkan melalui variabel rekomendasi dan kredibilitas informasi, adalah bahwa konsumen pada dasarnya; (1) mengantisipasi penyesalan; (2) lebih suka pada kondisi yang pasti (efek kepastian) dibandingkan tidak pasti; dan (3) pengaruh faktor rekomendasi terhadap penyealan hanya terjadi pada keputusan "tidak bertindak", sementara pada keputusan "bertindak", tidak signifikan pengaruhnya.

Saran bagi peneliti selanjutnya antara lain adalah penelitian tentang pengaruh faktor rekomendasi terhadap faktor penyesalan sebaiknya dipilah menjadi dua variabel, rekomendasi ahli dan rekomendasi non-ahli, yang berarti akan mempunyai dua hipotesis. Penelitian tentang faktor Penyesalan sangat dianjurkan menggunakan metode mix kuantitatif (eksprimen) dan kualitatif untuk dapat mengungkap faktor penyesalan secara memadai. Penelitian lanjutan perlu juga mengembangkan instrumen baku dari faktor penyesalan yang dalam penelitian belum sempat dilakukan.

\section{Kepustakaan}

Bell, D. E. (1982). Regret in decision making under uncertainty. Operation Research, 30(5), 961-981. Diunduh dari: http://www.jstor.org/Fri Aug 1 15: 42:00 2003

Connolly, T., Ordonez, L., D., \& Coughlan, R. (1997). Regret and responsibility in the evaluation of decision outcomes. Organizational Behavior and Human Decision Processes, 70(1), 73-85. http:// dx.doi.org/10.1006/obhd.1997.2695

Eckel, C. (2004). Men, Women and Risk Aversion: Experimental Evidence. Department of Economics, Virginia Tech. Diunduh dari: http://people. exeter.ac.uk/maf206/eckel_ grossman_ 2003.

Fitzsimons, G. J. (2000). Consumer response to stockouts, Journal of Consumer Research, 27, 249-266. http://dx.doi.org/ 5301/2001/2702-0007\$03.00.

Gilovich, T., \& Medvec, V. H. (1995). The experience of regret: what, when, and why? Psychological Review, 102(2), 379395. http://dx.doi.org/10.1037/0033295X.102.2.379

Kahneman, D. (1995). Varieties of counterfactual thinking. Dalam N.J. Roese \& J.M. Olson (Eds), What might have been: The social psychology of counterfactual thinking (hlm.375-396). Mahwah, NJ: Lawrence Erlbaum Associates, Inc.

Kahneman, D., \& Miller, D. T. (1986). Norm theory: Comparing reality to its alternatives. Psychological Review, 93(2), 136-153.

http://dx.doi.org/apa.org/journals/rev/ 93/2/136

Kahneman, D., \& Tversky, A. (1979). Prospect theory: an analysis of decision under risk, Econometrica, 47,263-291. Diunduh dari: http://links. jstor.org/sici Apr 5 17:18:55 2007.

Loomes, G., \& Sugden, R. (1982). Regret theory: an alternative theory of rational choice under uncertainty. The Economic Journal, 92, 805-824. Diunduh dari: http://www.jstor.org/Fri Nov. 25 04:14:26 2005

Loomes, G., \& Sugden, R. (1987). Testing for regret and disappointment in choice under uncertainty. The Economic Journal, 97, 118-129. Diunduh dari: http://www.jstor.org/stable/3038234

Myers, A., \& Hansen, C. (2002). Experimental Psychology, USA: Wadsworth Thomson Learning. 
Schwartz,B.(2004).Tyranny of choice. Scientific American, April. 23-29. Diunduh dari: http://journal.sjdm.org /12/12815/jdm12815.

Senecal, S., \& Nantel, J. (2004). The influence of online product recommendation on consumers'online choices. Journal of Retailing, 80, 159-169. Diunduh dari: http://www.sciencedirect. com/.../S0022435904000193

Seniati, L., Yulianto, A., \& Setiadi, B. N. (2008). Psikologi Eksperimen. Jakarta: PT. Indeks

Simon, H. A. (1955). A behavioral model of rational choice. The Quarterly Journal of Economics. 69, 99 118. Diunduh dari: http://www.jstor.org Wed Jan 17 22:49:52 2007

Simon, H. A. (2001). Theories of bounded rationality. Dalam P. E. Earl (Ed), The legacy of Herbert Simon in economic analysis (hlm.51-66). Cheltenham: Edwar Elgar Publishing Limited.

Tsiros, M., \& Mittal, V. (2000). Regret: a model of its antecedent and consequences in consumer decision making. Journal of Consumer Research, 26, 401-
417. http://dx.doi.org/0093.5301/2000/ 2604-0007S.0003

Zeelenberg, M., van Dijk, E., van den Bos, K., \& Pieters, R. (2002). The inaction effect in the psychology of regret. Journal of Personality and Social Psychology, 57, 445-455. http://dx. doi.org/10.1037//0022-3514.82.3.314

Zeelenberg, M., van Dijk, W., Manstead, A., \& van der Pligt, J. (1998). The experience of regret and disappointment. Cognition and Emotion, 12(2), 221$230 . \quad$ http://dx.doi.org/10.1080/ 026999398379727

Zeelenberg, M., van der Pligt, J., \& Vries, N. K. (2000) Attributions of responsibility and affective reactions to decision outcomes. Acta Psychologica, 104(2), 303-315. http://dx.doi.org/ 10.1016/S0001-6918(00)00034-2

Zeelenberg, M., \& Pieters, R. (2007). A theory of regret regulation 1.0. Journal of Consumer Psychology, 17(1), 3-18. Diunduh dari: https://www.tilburguniversity.edu/ upload/ea 